\title{
Ograniczenia dostępu do pornografii w internecie (kwestie braku definicji pojęcia pornografia oraz zobowiązań wynikających z konwencji genewskiej z 1923 r.) ${ }^{1}$
}

\footnotetext{
Restrictions on access to pornography in the Internet (issues of the lack of definition of pornography and obligations under the Geneva Convention of 1923): There is no comprehensive definition of pornography in the Polish legal system. The legislator only made a fragmentary definition of pornography in relation to "child pornography". In author's opinion an attempt to form a comprehensive definition of "pornography" or its semantic counterparts should take into account several fundamental issues, including the possibility to distinguish between pornography and eroticism. Solutions included in the International Convention of 1923 on Combating the Circulation and Trade of Pornographic Publications and in the Criminal Code were based on two non-complementary models of regulation regarding the access to pornography. Due to the partial outdating of reasons underlying the adoption of the above convention, the author of the opinion suggests to consider termination of the convention by Poland.
}

\author{
Keywords: internet, the Geneva Convention of 1923, pornography, Criminal \\ Code \\ Słowa kluczowe: internet, konwencja genewska z 1923 r., pornografia, Kodeks karny \\ Ekspert ds. legislacji BAS • pawel.bachmat@sejm.gov.pl • \\ https://orcid.org/0000-0003-3511-5425
}

\section{Przedmiot opinii}

W niniejszej opinii skoncentrowano się na kwestiach ustawowego zdefiniowania pojęcia treści pornograficznych oraz realizacji przez obowiązujący system prawa

\footnotetext{
Opinia prawna na temat ograniczenia dostęu do pornografii w Internecie (kwestie: definicji pojęcia oraz zobowiąań wynikających z konwencji genewskiej z 1923 r.) sporządzona 23 stycznia 2019 r. na zlecenie posła Klubu Parlamentarnego Prawo i Sprawiedliwość; BAS-WAP 1866/18.
} 
wymogów Konwencji genewskiej z dnia 12 września 1923 r. w sprawie zwalczania obiegu i handlu wydawnictwami pornograficznymi.

Opinia uwzględnia stan prawny na dzień jej sporządzenia, została przygotowana na podstawie następujących aktów normatywnych:

- ustawa z 6 czerwca 1997 r. - Kodeks karny, t.j. Dz.U. 2017, poz. 2204, ze zm.; dalej: Kodeks karny lub k.k.,

- Międzynarodowa Konwencja w sprawie zwalczania obiegu i handlu wydawnictwami pornograficznemi [pisownia oryginalna - P.B.], podpisana 12 września 1923 r. w Genewie, Dz.U. 1927, nr 71, poz. 621, ze zm.; dalej: konwencja genewska,

- protokół fakultatywny do Konwencji o prawach dziecka w sprawie handlu dziećmi, dziecięcej prostytucji i dziecięcej pornografii, przyjęty w Nowym Jorku 25 maja 2000 r., Dz.U. 2007, nr 76, poz. 494; dalej: protokół fakultatywny z 2000 r.,

- Konwencja Rady Europy o cyberprzestępczości, sporządzona w Budapeszcie 23 listopada 2001 r., Dz.U. 2015, poz. 728; dalej: konwencja budapeszteńska,

- Konwencja Rady Europy o ochronie dzieci przed seksualnym wykorzystywaniem i niegodziwym traktowaniem w celach seksualnych, sporządzona w Lanzarote 5 października 2007 r., Dz.U. 2015, poz. 608; dalej: konwencja z Lanzarote,

- ustawa z 19 kwietnia 1969 r. - Kodeks karny, Dz.U. nr 13, poz. 94, ze zm.; dalej: Kodeks karny z 1969 r.,

- rozporządzenie Prezydenta Rzeczypospolitej z 11 lipca 1932 r. - Kodeks karny, Dz.U. nr 60, poz. 571, ze zm.; dalej: Kodeks karny z 1932 r.,

- ustawa z 5 lipca 2018 r. o krajowym systemie cyberbezpieczeństwa, Dz.U. poz. 1560; dalej: u.k.s.c.,

- rozporządzenie Krajowej Rady Radiofonii i Telewizji 23 czerwca 2005 r. w sprawie kwalifikowania audycji lub innych przekazów mogących mieć negatywny wpływ na prawidłowy fizyczny, psychiczny lub moralny rozwój małoletnich oraz audycji lub innych przekazów przeznaczonych dla danej kategorii wiekowej małoletnich, stosowania wzorów symboli graficznych i formuł zapowiedzi, t.j. Dz.U. 2014, poz. 311; dalej: rozporządzenie KRRiT,

- dyrektywa Parlamentu Europejskiego i Rady 2011/92/UE z 13 grudnia 2011 r. $\mathrm{w}$ sprawie zwalczania niegodziwego traktowania w celach seksualnych i wykorzystywania seksualnego dzieci oraz pornografii dziecięcej, zastępująca decyzję ramową Rady 2004/68/WSiSW, Dz.Urz. UE L 335 z 17 grudnia 2011 r.; dalej: dyrektywa z $2011 \mathrm{r}$.,

- ustawa z 29 grudnia 1992 r. o radiofonii i telewizji, t.j. Dz.U. 2017, poz. 1414, ze zm.; dalej: u.r.i.t.,

- rozporządzenie Ministra Edukacji Narodowej z 14 lutego 2017 r. w sprawie podstawy programowej wychowania przedszkolnego oraz podstawy programowej kształcenia ogólnego dla szkoły podstawowej, w tym dla uczniów 
z niepełnosprawnością intelektualną w stopniu umiarkowanym lub znacznym, kształcenia ogólnego dla branżowej szkoły I stopnia, kształcenia ogólnego dla szkoły specjalnej przysposabiającej do pracy oraz kształcenia ogólnego dla szkoły policealnej, Dz.U. poz. 356, ze zm.,

- rozporządzenie Ministra Nauki i Szkolnictwa Wyższego z 9 maja 2012 r. w sprawie standardów kształcenia dla kierunków studiów: lekarskiego, lekarsko-dentystycznego, farmacji, pielęgniarstwa i położnictwa, t.j. Dz.U. 2018, poz. 345,

- Konstytucja Rzeczypospolitej Polskiej z 2 kwietnia 1997 r., Dz.U. nr 78, poz. 483, ze zm.; dalej: Konstytucja RP,

- konwencja o ochronie praw człowieka i podstawowych wolności, sporządzona w Rzymie 4 listopada 1950 r., Dz.U. 1993, nr 61, poz. 284, ze zm.; dalej: europejska konwencja praw człowieka.

\section{Uzasadnienie prawne}

\section{Brak ustawowej definicji treści pornograficznych}

1. W polskim systemie prawa nie występuje całościowa definicja pojęcia „pornografii” ani jego odpowiedników (np. „treści pornograficznych” czy „materiałów mających charakter pornograficzny”), choć wymienione kategorie pojęć zostały wprowadzone do dyspozycji przepisów nie tylko na gruncie prawa karnego, ale także prawa administracyjnego i ratyfikowanych aktów prawa międzynarodowego będących samodzielnym źródłem prawa obowiązującego w Polsce. Skutkuje to tym, że w konkretnych przypadkach objętych relewantną regulacją to organ stosujący prawo (policja, prokuratura, sąd, Krajowa Rada Radiofonii i Telewizji, inne organy) będzie zobligowany do dokonania oceny, czy ma do czynienia $\mathrm{z}$ materiałem lub treścią pornograficzną oraz w dalszej kolejności przypisania wynikających z tego faktu konsekwencji prawnych. Słowo „ocena” jest tutaj kluczowe. Jak bowiem wskazuje się w literaturze przedmiotu, termin "pornografia” (a także jego semantyczne odpowiedniki normatywne) ma charakter ocenny, zawsze więc ostateczna decyzja co do identyfikacji i wskazania desygnatów tych pojęć należeć będzie do podmiotu oceniającego ${ }^{2}$. Zapewne też z tą właściwością terminu „pornografia” wiązać należy niechęć ustawodawcy do ujęcia go w granicach wyznaczonych definicją ustawową. $Z$ tego względu każda pozaustawowa definicja pornografii czy też próba ich skonstruowania powinna być traktowana w obowiązującym stanie prawnym nie jako uniwersalny i zobiektywizowany wzorzec, a jedynie jako narzędzie wspomagające w procesie dokonywania ocen

2 Za: M. Filar, Przestępstwa seksualne w nowym kodeksie karnym [w:] Nowa kodyfikacja karna. Kodeks karny. Krótkie komentarze, z. 2, Warszawa 1997, s. 39-40. 
przez organ stosujący prawo ${ }^{3}$. Warto $\mathrm{w}$ tym miejscu przywołać również pogląd Sądu Najwyższego, który w wyroku z 23 listopada 2010 r. ${ }^{4}$ jednoznacznie identyfikuje pojęcie „treści pornograficznych” jako kategorię normatywną, o zaistnieniu której w badanym stanie faktycznym zawsze ostatecznie decyduje w drodze oceny organ stosujący prawo, w tym przypadku sąd, a nie np. biegły z zakresu seksuologii. Na gruncie analizy znamion typu czynu zabronionego z art. 202 $\$ 3$ k.k. SN wskazał, iż znamię „treści pornograficzne” jest pojęciem prawnym, a nie medycznym czy seksuologicznym, zaś biegły seksuolog posiada wiadomości specjalne jedynie w zakresie ustalenia hipotetycznego wpływu danej prezentacji na potencjalnego odbiorcę w płaszczyźnie jego reakcji emocjonalnych, w tym seksualnych. Żaden biegły, zdaniem SN, w tym i biegły seksuolog, nie jest $\mathrm{w}$ stanie zastąpić sądu w ocenie istnienia tego znamienia $\mathrm{w}$ danej prezentacji.

2. Brak całościowego, normatywnego ujęcia terminu pornografia, które przybrałoby formę definicji ustawowej, nie oznacza, że polski ustawodawca całkowicie odrzuca możliwość ujęcia tego pojęcia w ramach rygoru definicji. W obowiązującym systemie prawa można bowiem zidentyfikować przypadki, w których ustawodawca dopuścił próby wycinkowego zdefiniowania pornografii w odniesieniu do „pornografii dziecięcej”. Elementem polskiego porządku prawnego stała się (po dokonaniu ratyfikacji przez Prezydenta RP poprzedzonego zgodą wyrażoną w formie ustawy) m.in. konwencja budapeszteńska, która w art. 9 ust. 2 wprowadza definicję „pornografii dziecięcej” dla potrzeb realizacji przez państwa strony obowiązku kryminalizacji zachowań wymienionych w art. 9 ust. 1. W myśl tego uregulowania „pornografia dziecięca” obejmuje materiał pornograficzny, który w sposób widoczny przedstawia:

- osobę małoletnią w trakcie czynności wyraźnie seksualnej,

- osobę, która wydaje się być małoletnią, w trakcie czynności wyraźnie seksualnej,

- realistyczny obraz przedstawiający osobę małoletnią w trakcie czynności wyraźnie seksualnej.

Tytułem uzupełnienia konwencja budapeszteńska przyjmuje, że „osobą małoletnią” będzie w jej rozumieniu każda osoba poniżej 18. roku życia. Jednocześnie państwo strona może wprowadzić wymóg niższej granicy wieku, która nie może być niższa niż 16 lat.

3 Za: J. Warylewski, Rozdział IV. Przestępstwa przeciwko wolności seksualnej i obyczajności [w:] System prawa karnego, t. 10, Przestępstwa przeciwko dobrom indywidualnym, red. J. Warylewski, Warszawa 2016, s. 889, nb 598.

4 Sygn. akt IV KK 173/10, LEX nr 667510. Podobny pogląd do stanowiska SN prezentuje w polskim piśmiennictwie karnistycznym m.in. M. Filar, Pornografia, „Przegląd Ustawodawstwa Gospodarczego" 1993, nr 8-9, s. 24, LEX nr 11192/2. 
Na tej samej zasadzie częścią polskiego porządku prawnego stała się konwencja z Lanzarote z 2007 r., która również definiuje pojęcie „pornografii dziecięcej”, będącej znamieniem przestępstw, do kryminalizacji których w krajowym porządku prawnym konwencja ta zobowiązuje państwa strony. Zgodnie $\mathrm{z}$ art. 20 ust. 2 konwencji z Lanzarote „pornografia dziecięca” oznacza jakikolwiek materiał, który wizualnie przedstawia dziecko uczestniczące w rzeczywistej lub udawanej czynności wyraźnie seksualnej lub jakiekolwiek przedstawianie narządów płciowych dziecka głównie w celach seksualnych (zasadniczo obejmuje to także materiały składające się wyłącznie z udawanego przedstawiania lub realistycznych obrazów nieistniejącego dziecka). Z kolei, zgodnie z art. 21 ust. 2 konwencji z Lanzarote, dla potrzeb kryminalizacji zachowań określonych w art. 21, „pornografia dziecięca” obejmuje materiał pornograficzny, który w sposób widoczny przedstawia:

- osobę małoletnią w trakcie czynności wyraźnie seksualnej,

- osobę, która wydaje się być małoletnią, w trakcie czynności wyraźnie seksualnej,

- realistyczny obraz przedstawiający osobę małoletnią w trakcie czynności wyraźnie seksualnej.

Definicję „pornografii dziecięcej zawiera również art. 2c protokołu fakultatywnego $\mathrm{z}$ roku 2000 do konwencji o prawach dziecka w sprawie handlu dziećmi, dziecięcej prostytucji i dziecięcej pornografii. Powołany przepis stanowi, że dziecięca pornografia oznacza jakiekolwiek pokazywanie, za pomocą dowolnych środków, dziecka uczestniczącego w rzeczywistych lub symulowanych ewidentnie czynnościach seksualnych lub też jakiekolwiek pokazywanie organów płciowych w celach przede wszystkim seksualnych.

Terminem „pornografia dziecięca” posługuje się także ustawa z 5 lipca $2018 \mathrm{r}$. o krajowym systemie cyberbezpieczeństwa, która, egzemplifikując zadania Zespołu Reagowania na Incydenty Bezpieczeństwa Komputerowego działającego na poziomie krajowym, prowadzonego przez Naukową i Akademicką Sieć Komputerową - Państwowy Instytut Badawczy (CSIRT NASK), w przepisie art. 26 ust. 6 pkt 3 zalicza do nich: zapewnienie obsługi linii telefonicznej lub serwisu internetowego prowadzących działalność w zakresie zgłaszania i analizy przypadków dystrybucji, rozpowszechniania lub przesyłania pornografii dziecięcej za pośrednictwem technologii informacyjno-komunikacyjnych, o których mowa w dyrektywie Parlamentu Europejskiego i Rady 2011/92/UE z 13 grudnia 2011 r. w sprawie zwalczania niegodziwego traktowania w celach seksualnych i wykorzystywania seksualnego dzieci oraz pornografii dziecięcej, zastępującej decyzję ramową Rady 2004/68/WSiSW (Dz.Urz. UE L 335 z 17 grudnia 2011, s. 1). W ujęciu przyjętym w powołanej dyrektywie przez „pornografię dziecięcą” rozumie się, zgodnie $\mathrm{z}$ jej art. $2 \mathrm{c}$ :

- wszelkie materiały ukazujące dziecko uczestniczące w rzeczywistych lub symulowanych zachowaniach o wyraźnie seksualnym charakterze, 
- wszelkie przedstawienia organów płciowych dziecka w celach głównie seksualnych,

- wszelkie materiały ukazujące osobę wyglądającą na dziecko uczestniczącą w rzeczywistych lub symulowanych zachowaniach o wyraźnie seksualnym charakterze oraz przedstawienia organów płciowych osób wyglądających jak dziecko, w celach głównie seksualnych lub realistyczne obrazy dziecka uczestniczącego w zachowaniach o wyraźnie seksualnym charakterze lub realistyczne obrazy organów płciowych dziecka, w celach głównie seksualnych.

Z kolei stosownie do art. 2e dyrektywy z 2011 r. „przedstawienie pornograficzne" oznacza skierowane do publiczności ukazywanie na żywo, w tym za pośrednictwem technologii informacyjno-komunikacyjnych:

- dziecka uczestniczącego w rzeczywistym lub symulowanym zachowaniu o wyraźnie seksualnym charakterze,

- organów płciowych dziecka, w celach głównie seksualnych.

Dzieckiem w rozumieniu dyrektywy z 2011 r. jest każda osoba w wieku poniżej 18 lat (art. 2a).

3. Podejście polskiego prawodawcy, który nie zdecydował się na wytworzenie jednej, zakresowo zupełnej definicji pornografii, nawet na gruncie prawa karnego, ma charakter utrwalony. Definicji pornografii nie zawierał Kodeks karny z 1932 r., który posługiwał się na gruncie typizacji z art. $214 \$ 1$ i 2 znamieniem „przedmiotów mających charakter pornograficzny”, ani też Kodeks karny z 1969 r., który do tego samego znamienia odwoływał się na gruncie typizacji z art. $173 \$ 1$ i $2^{6}$. Obowiązujący Kodeks karny z roku 1997 - mimo przeprowadzonej po jego wejściu w życie nowelizacji artykułów, w których określono przestępstwa pornograficzne - nie odstąpił od tej praktyki. Przy opisie typów czynów zabronionych posługuje się znamieniem „treści pornograficznych” (art. $200 \$ 3$ i 5, art. 200a $\$ 1$ i 2 , art. $202 \$ 1,3,4,4$ a, 4c), ,przedmiotów mających charakter pornograficzny” (200 $\$ 3$ ), a w niektórych przypadkach nie używa słowa „pornografia”, choć z przyjętej stylizacji przepisu jednoznacznie wynika, że do takiej treści odwołuje się za pomocą inaczej wysłowionych znamion (por. 191a $₫ 1$ w zakresie rozpowszechniania bez zgody osoby jej „wizerunku w trakcie czyn-

$5 \quad$ Art. 214 k.k. z 1932 r. stanowił: $\$ 1$. Kto rozpowszechnia pisma, druki, wizerunki lub inne przedmioty, majace charakter pornograficzny, podlega karze aresztu do lat 2.

$\$ 2$. Tej samej karze podlega, kto w celu rozpowszechnienia takie pisma, druki, wizerunki lub przedmioty sporzadza, przechowuje lub przewozi.

$6 \quad$ Art. 173 k.k. z 1969 r. stanowił: $\$ 1$. Kto rozpowszechnia pisma, druki, fotografie lub inne przedmioty mające charakter pornograficzny, podlega karze pozbawienia wolności do lat 2, ograniczenia wolności albo grzywny.

$\$ 2$. Tej samej karze podlega, kto w celu rozpowszechnienia takie pisma, druki, fotografie lub przedmioty sporządza, przechowuje, przenosi, przesyła lub przewozi. 
ności seksualnej”, art. $200 \$ 4 \mathrm{w}$ zakresie prezentowania małoletniemu poniżej lat 15 wykonania czynności seksualnej oraz, jak się wydaje, także art. 200b przynajmniej w części zakresu propagowania zachowań o charakterze pedofilskim).

Zakaz kierowania „treści pornograficznych” do osób małoletnich wynika także z ustawy z 29 grudnia 1992 r. o radiofonii i telewizji, która reguluje rynek dostawców usług medialnych ustanowionych na terytorium Rzeczypospolitej Polskiej (art. 1a u.r.i.t.), oraz przepisów wykonawczych wydanych na jej podstawie przez Krajową Radę Radiofonii i Telewizji, w szczególności z rozporządzenia Krajowej Rady Radiofonii i Telewizji z 23 czerwca 2005 r. w sprawie kwalifikowania audycji lub innych przekazów mogących mieć negatywny wpływ na prawidłowy fizyczny, psychiczny lub moralny rozwój małoletnich oraz audycji lub innych przekazów przeznaczonych dla danej kategorii wiekowej małoletnich, stosowania wzorów symboli graficznych i formuł zapowiedzi (dalej: rozporządzenie KRRiT). Stosownie do art. 18 u.r.i.t. audycje lub inne przekazy nie mogą sprzyjać zachowaniom zagrażającym zdrowiu lub bezpieczeństwu oraz zachowaniom zagrażającym środowisku naturalnemu (ust. 3). Zabronione jest rozpowszechnianie audycji lub innych przekazów zagrażających fizycznemu, psychicznemu lub moralnemu rozwojowi małoletnich, w szczególności zawierających treści pornograficzne lub w sposób nieuzasadniony eksponujących przemoc (ust. 4). Audycje lub inne przekazy, zawierające sceny lub treści mogące mieć negatywny wpływ na prawidłowy fizyczny, psychiczny lub moralny rozwój małoletnich, inne niż te, o których mowa w ust. 4, mogą być rozpowszechniane wyłącznie w godzinach od 23 do 6 (ust. 5). Nadawcy są zobowiązani do oznaczania audycji lub innych przekazów, o których mowa w ust. 5, odpowiednim symbolem graficznym przez cały czas ich emisji telewizyjnej lub zapowiedzią słowną, informującą o zagrożeniach wynikających z treści emisji radiowej (ust. 5a). Nadawcy są zobowiązani do oznaczania audycji i innych przekazów, innych niż te, o których mowa w ust. 5, z wyłączeniem serwisów informacyjnych, reklam, telesprzedaży, transmisji sportowych i przekazów tekstowych, odpowiednim symbolem graficznym przez cały czas ich emisji telewizyjnej, uwzględniając stopień szkodliwości danej audycji lub przekazu dla małoletnich w poszczególnych kategoriach wiekowych (ust. 5b). Krajowa Rada określi, w drodze rozporządzenia:

- cechy oraz szczegółowe warunki kwalifikowania, rozpowszechniania i sposób zapowiadania audycji lub innych przekazów, o których mowa w ust. 5,

- podział małoletnich na kategorie wiekowe oraz szczegółowe warunki kwalifikowania i rozpowszechniania audycji lub innych przekazów, o których mowa w ust. 5b, z uwzględnieniem godzin nadawania audycji lub innych przekazów przeznaczonych dla danej kategorii wiekowej,

- wzory symboli graficznych i formuł zapowiedzi, o których mowa w ust. 5a i $5 b$, oraz sposób ich prezentacji,

- uwzględniając stopień szkodliwości audycji dla małoletnich w poszczególnych kategoriach wiekowych (ust. 6). 
Dnia 25 czerwca 2005 r. Krajowa Rada Radiofonii i Telewizji wydała przedmiotowe rozporządzenie (powoływane wcześniej jako rozporządzenie KRRiT), które w aktualnej wersji obowiązuje od 14 marca 2014 r.

Do problematyki zagrożeń, jakie niesie ze sobą pornografia, prawodawca odwołuje się także w rozporządzeniach regulujących podstawę programową w szkolnictwie. Przy okazji określenia obligatoryjnych elementów programu nauczania odnosi się m.in. do zjawiska pornografii. Wprowadzając do dyspozycji odnośnych przepisów pojęcie „pornografii”, nie definiuje go jednak dla potrzeb wykładni tych aktów prawnych. Dla przykładu, Minister Edukacji Narodowej w rozporządzeniu z 14 lutego 2017 r. w sprawie podstawy programowej wychowania przedszkolnego oraz podstawy programowej kształcenia ogólnego dla szkoły podstawowej, w tym dla uczniów z niepełnosprawnością intelektualną w stopniu umiarkowanym lub znacznym, kształcenia ogólnego dla branżowej szkoły I stopnia, kształcenia ogólnego dla szkoły specjalnej przysposabiającej do pracy oraz kształcenia ogólnego dla szkoły policealnej, jako element programu nauczania w zakresie przedmiotu wychowanie do życia w rodzinie czyni uświadomienie uczniom, obok innych, także zagrożeń wynikających z pornografii (zob. załącznik nr 2 - Podstawa programowa kształcenia ogólnego dla szkoły podstawowej; załącznik nr 4 - Podstawa programowa kształcenia ogólnego dla branżowej szkoły I stopnia dla uczniów będących absolwentami dotychczasowego gimnazjum; załącznik nr 4a - Podstawa programowa kształcenia ogólnego dla branżowej szkoły I stopnia dla uczniów będących absolwentami ośmioletniej szkoły podstawowej). Z kolei Minister Nauki i Szkolnictwa Wyższego w rozporządzeniu z 9 maja 2012 r. w sprawie standardów kształcenia dla kierunków studiów: lekarskiego, lekarsko-dentystycznego, farmacji, pielęgniarstwa i położnictwa przyjął założenie, że studenci studiów drugiego stopnia kierunku położnictwo powinni m.in. zdołać określić wpływ na psychikę dzieci i młodzieży zagadnień obyczajowych, takich jak pornografia i „moda na seks” (zob. załącznik nr 5 - Standardy kształcenia dla kierunku studiów: położnictwo).

4. Należy zastrzec, że wykorzystanie przez ustawodawcę pojęcia ocennego lub językowo niedookreślonego przy konstruowaniu przepisu prawa nie stanowi naruszenia zasad poprawnej legislacji (wywodzonych wprost z art. 2 Konstytucji RP) ani określoności czynu zabronionego (art. 42 ust. 1 Konstytucji RP), o ile adresat zdekodowanej na podstawie takiego przepisu normy będzie mógł zidentyfikować jego desygnaty, np. wykorzystując poglądy doktryny czy orzecznictwo sądowe, które w drodze wykładni zdołało usunąć istniejące wątpliwości.

Powyższe stanowisko znajduje odzwierciedlenie w licznych judykatach Trybunału Konstytucyjnego, który niejednokrotnie wskazywał, że nawet najdalej idące wymagania określoności, stawiane przez Konstytucję ustawodawcy, nie wykluczają całkowicie możliwości użycia w przepisach prawnych zwrotów językowych niedookreślonych lub ocennych. Dla przykładu w uchwale z 6 listopada 
1991 r., sygn. akt W 2/917, Trybunał orzekł, że: posługiwania się w prawie [...] pojęciami nieostrymi nie można a priori traktować jako uchybienia legislacyjnego. Często bowiem skonstruowanie określonej normy prawnej przy ich pomocy stanowi jedyne rozsądne wyjście. Na straży właściwego zastosowania takiej normy stoja przede wszystkim normy procesowe, nakazujace wykazanie przesłanek, jakie legły u podstaw zastosowania w konkretnej sprawie normy prawnej skonstruowanej przy użyciu tego rodzaju nieostrego pojęcia ${ }^{8}$. Z kolei w wyroku z 12 września 2005 r., sygn. akt SK 13/05, Trybunał uznał, że: zasada określoności ustawy karnej nie wyklucza [...] posługiwania się przez ustawodawcę zwrotami niedookreślonymi lub ocennymi, jeśli ich desygnaty można ustalić. Rozwijając tę tezę, Trybunał zaznaczył, że: sam kodeks karny operuje licznymi zwrotami niedookreślonymi, które nie maja wyłącznie na celu oznaczenia kwalifikowanej postaci przestępstwa. Wystarczy wskazać na art. 218 \& 1 k.k. - mówiący o oddziaływaniu „złośliwym”, art. 304 k.k. - mówiący o „przymusowym położeniu”, art. 311 k.k. - „istotne znaczenie", gdzie użycie takich zwrotów determinuje same znamiona czynu karalnego. Znaczenie tych określeń nie jest jednak ustalane w próżni prawnej, co mogłoby rodzić niepewność, lecz poprzez analizę dorobku doktryny, a zwłaszcza orzecznictwa sądowego, które autorytatywnie usuwa istniejące obiektywnie wątpliwości.

Biorąc powyższe pod uwagę, nie wydaje się, aby podejście polskiego ustawodawcy, który nie zdecydował się na wytworzenie jednej, zakresowo zupełnej definicji pojęcia „pornografii” ani jego normatywnych odpowiedników (np. „treści pornograficznych” czy „materiałów mających charakter pornograficzny), kreowało per se stan niekonstytucyjności. Adresat relewantnych przepisów, w których wykorzystane zostały pojęcia „pornografii”, „treści pornograficznych”, „materiałów mających charakter pornograficzny” itp., może z powodzeniem starać się odtworzyć ich zakres normatywny przy wykorzystaniu licznych poglądów doktryny oraz orzecznictwa, w których starano się wypracować wskazówki pozwalające na zidentyfikowanie ich faktycznych desygnatów.

Według wykładni Sądu Najwyższego, przedstawionej w wyroku z 23 listopada 2010 r. ${ }^{10}$, znamię "treści pornograficznych" jest interpretowane w następujący sposób: Treści pornograficzne w rozumieniu art. 202 k. $k$. to zawarte w utrwalonej formie (np. film, zdjęcia, czasopisma, książki, obrazy) lub nie (np. pokazy na żywo), prezentacje czynności seksualnych człowieka (zwłaszcza ukazywanie organów płciowych człowieka $w$ ich funkcjach seksualnych), i to zarówno $w$ wymiarze niesprzecznym z ich biologicznym ukierunkowaniem, jak i czynności seksualnych człowieka sprzecznych z przyjętymi w społeczeństwie wzorcami zacho-

OTK 1991, poz. 20, cz. IV, pkt 5.

8 Cytowane stanowisko Trybunał Konstytucyjny powtórzył następnie w wyroku z 25 lutego 2014 r., sygn. akt SK 65/12, Dz.U. 2014, poz. 268.

9 OTK-A ZU 2005, nr 8, poz. 91, cz. III, pkt 2.4.

10 Sygn. akt IV KK 173/10, LEX nr 667510. 
wań seksualnych. W dalszej części cytowanego orzeczenia SN wskazał m.in., że: [d]zieła artystyczne, a także dzieła naukowe moga jednocześnie zwierać treści pornograficzne, zaś brak karalności produkcji, prezentacji i rozpowszechniania takich dzieł, wynika, jak się wydaje, $z$ istnienia pozaustawowego kontratypu sztuki i nauki. Istota pornografii jest przekaz określonej idei (treści), a nie jedynie udokumentalizowanej rejestracji określonego wydarzenia faktycznego. Sformułowanie treści pornograficzne związane z prezentowaniem przemocy użyte $w$ art. $202 \$ 3 k . k$. obejmuje swoim zakresem także przedstawianie odegranych przez aktorów scen przemocy powiązanych $z$ treściami, o jakich mowa $w$ powołanym wyżej przepisie, jak też tego rodzaju sceny wytworzone za pomoca różnych innych technik wizualizacji.

W wyroku z 11 stycznia 2017 r. ${ }^{11}$ Sąd Najwyższy orzekł, że do cech, których łączne występowanie pozwala na uznanie treści ocenianego przekazu za pornograficzny, należą: a) przedstawianie płciowości i życia płciowego człowieka, b) koncentrowanie się wyłącznie na technicznych aspektach płciowości i życia płciowego $\mathrm{z}$ pominięciem wszelkiej warstwy intelektualno-personalitycznej, c) ukazywanie ludzkich narządów płciowych w ich funkcjach seksualnych, d) przebijająca $z$ treści przekazu główna intencja twórcy, jaką jest wywołanie podniecenia seksualnego u odbiorcy.

Z kolei na gruncie polskiej doktryny prawa największe znaczenie uzyskały poglądy M. Filara i J. Warylewskiego. M. Filar wskazuje w swojej analizie, że pojęcie pornografia ma charakter wybitnie ocenny i społeczno-prawny, przez co odrywa się od zagadnień związanych wyłącznie z biologiczną i seksualną (medyczno-seksuologiczną) stroną życia. Autor ten identyfikuje cechy, które muszą wystąpić łącznie, aby uznać, że określone treści mają pornograficzny charakter. Należą do nich:

- przedstawianie przejawów płciowości i życia płciowego człowieka,

- koncentrowanie się wyłącznie na technicznych aspektach płciowości i życia płciowego z całkowitym oderwaniem od warstwy intelektualnej i osobistej,

- ukazywanie ludzkich organów płciowych w ich funkcjach seksualnych, w szczególności w ich bezpośrednim zetknięciu się podczas stosunków seksualnych, co sprowadza się do rejestracji zdepersonalizowanej i odhumanizowanej technologii seksu,

- wymienione cechy wskazują jednoznacznie, że jedyną lub główną intencją twórcy było wywołanie podniecenia seksualnego u odbiorcy,

- kryterium pomocniczym ma być walor estetyczny - im jest on niższy, tym bliżej takim treściom do pornografii ${ }^{12}$.

11 Sygn. akt III KK 188/16, LEX nr 2321853.

12 M. Filar, Przestępstwa seksualne, op. cit., s. 39-40; idem, Przestęstwa seksualne w polskim prawie karnym, Toruń 1985. 
W ujęciu J. Warylewskiego „treści pornograficzne” oraz synonimiczna dla nich „pornografia”, w rozumieniu wąskim (normatywnym), to treści, zawarte w dającym się wyodrębnić przekazie informacyjnym (prezentacji) bądź w jego istotnych i odpowiednio spójnych fragmentach, w formie materialnej lub zdematerializowanej, utrwalone za pomocą dowolnego nośnika lub nieutrwalone, charakteryzujące się tym, iż przedstawiają w jakiejkolwiek formie autentyczne lub tylko wyobrażone (wykreowane) przejawy płciowości lub życia seksualnego człowieka w wymiarze ograniczonym (sprowadzonym) do funkcji fizjologicznych oraz aspektów techniczno-biologicznych ${ }^{13}$.

5. Biorąc pod uwagę ustalenia przedstawione powyżej, można przyjąć, że wprowadzenie do polskiego porządku prawnego nowych przepisów ukierunkowanych na ograniczenie dostępu do pornografii w internecie nie musi bezwzględnie wiązać się z koniecznością ustawowego zdefiniowania tego pojęcia, i to pomimo jego ocennego charakteru. Dotyczy to również semantycznych odpowiedników normatywnych pojęcia „pornografia”, takich jak „treści pornograficzne”, „materiały mające charakter pornograficzny” i inne. Choć tego typu przepisy inkorporują w sobie normy o charakterze nakazu lub zakazu, i z tego względu powinny zostać wysłowione przez ustawodawcę w sposób niebudzący wątpliwości po stronie ich adresata, będzie istniała możliwość zdekodowania ich zakresu normatywnego na podstawie dotychczasowych poglądów doktryny oraz stanowisk wyrażonych w orzecznictwie, w ramach których starano się wypracować wskazówki pozwalające na zidentyfikowanie faktycznych desygnatów pojęcia „pornografia”. W świetle orzecznictwa Trybunału Konstytucyjnego, dotyczącego dopuszczalności stosowania pojęć ocennych lub językowo nieostrych pod warunkiem możliwości ustalenia ich desygnatów przy wykorzystaniu kryteriów wypracowanych w doktrynie lub orzecznictwie, taki stan rzeczy nie prowadzi per se do naruszenia konstytucyjnego wymogu poprawnej legislacji (art. 2 Konstytucji RP), czy - to już na gruncie prawa karnego - określoności czynu zabronionego (art. 42 ust. 1 Konstytucji RP).

Z drugiej strony ewentualna ustawowa propozycja zdefiniowania pojęcia „pornografii” lub jego semantycznego odpowiednika normatywnego, wykorzystanego w treści przyszłego projektu, może w założeniu przyczynić się do podniesienia stopnia czytelności i pewności prawa w odbiorze jego adresatów. To stanie się jednak tylko pod warunkiem, że próba ujęcia pojęcia „pornografii” w rygory definicji normatywnej powiedzie się. Źle wyznaczone granice definicji ustawowej, niewłaściwy dobór kryteriów (przesłanek), składających się na definiens kategorii definiowanej, czy wykorzystanie w tym celu pojęć o niejasnym zakresie przynależnych desygnatów (pojęć, które same wymagałyby zdefiniowania), nie tylko utrudni stosowanie w praktyce nowo wprowadzanych przepisów, ale może również zdestabilizować opartą na wykładni praktykę stosowania

13 J. Warylewski, Rozdział IV. Przestępstwa przeciwko, op. cit., s. 889, nb 598. 
przepisów wcześniej obowiązujących, w dyspozycjach których wykorzystano już to pojęcie. W przypadku pojęcia „pornografii” (lub jego semantycznych odpowiedników normatywnych) ewentualna próba ujęcia go w ramach definicji ustawowej powinna w sposób satysfakcjonujący rozstrzygnąć na gruncie przepisu prawa co najmniej takie kwestie, jak:

- kryteria rozgraniczenia między pornografią a erotyką,

- ogromna różnorodność przejawów płciowości i życia seksualnego człowieka,

- potrzeba uwzględnienia kwestii autentyczności i sztucznej kreacji przejawów płciowości i życia seksualnego oraz ich uczestników,

- różnorodność potencjalnych form przekazu lub nośników treści,

- pytanie o dopuszczalność pornografii w przekazie artystycznym lub naukowym (kontratyp sztuki i nauki) ${ }^{14}$.

\section{Konwencja genewska z 1923 r. - jej miejsce w polskim porządku prawnym oraz wyznaczony standard kryminalizacji}

1. Międzynarodowa konwencja w sprawie zwalczania obiegu i handlu wydawnictwami pornograficznemi, podpisana 12 września $1923 \mathrm{r}$ w Genewie, została ratyfikowana przez Prezydenta RP 13 stycznia 1927 r. (Dz.U. nr 71, poz. 621, ze $\mathrm{zm}$.), po uzyskaniu uprzedniej zgody Sejmu wyrażonej w formie ustawy ${ }^{15}$. W odniesieniu do Polski weszła w życie 8 marca 1927 r. $^{16}$. Do dzisiaj nie została przez Polskę wypowiedziana, stosownie do brzmienia jej artykułu XII.

Obecny status konwencji genewskiej z $1923 \mathrm{r}$. w polskim porządku prawnym wynika z przepisów Konstytucji. Przede wszystkim znajduje do niej zastosowanie przepis przejściowy art. 241 ust. 1 Konstytucji RP, zgodnie z którym umowy międzynarodowe ratyfikowane dotychczas przez Rzeczpospolitą Polską na podstawie obowiązujących w czasie ich ratyfikacji przepisów konstytucyjnych i ogłoszone w Dzienniku Ustaw uznaje się za umowy ratyfikowane za uprzednią zgodą wyrażoną w ustawie i stosuje się do nich przepisy art. 91 Konstytucji, jeżeli z treści umowy międzynarodowej wynika, że dotyczą one kategorii spraw

14 Szerzej na temat kwestii dopuszczalności treści pornograficznych w przekazie artystycznym lub naukowym zob. J. Warylewski, Rozdział IV. Przestępstwa przeciwko wolności, op. cit., s. 890-894; M. Budyn-Kulik, Glosa do wyroku SN z dnia 23 listopada 2010 r., IV KK 173/10, LEX nr 125982.

15 Ustawa z 31 lipca 1926 r. w sprawie ratyfikacji międzynarodowej konwencji o zwalczaniu obiegu i handlu publikacjami pornograficznemi i dołączonego do niej aktu końcowego, podpisanych w Genewie 12 września 1923 r., Dz. U. nr 93, poz. 537.

16 Konwencja weszła w życie w odniesieniu do Polski wraz ze złożeniem w Sekretariacie Ligi Narodów 8 marca 1927 r. dokumentu ratyfikacyjnego; zob. Oświadczenie rządowe z dnia 18 czerwca 1927 r. w sprawie złożenia w Sekretarjacie Ligi Narodów dokumentu ratyfikacyjnego międzynarodowej konwencji w sprawie zwalczania obiegu i handlu wydawnictwami pornograficznemi, podpisanej dnia 12 września $1923 \mathrm{r}$. w Genewie, Dz.U. 1927, nr 71, poz. 622. 
wymienionych w art. 89 ust. 1 Konstytucji (w tym przypadku relewantna jest przesłanka: wolności i praw określonych w ustawie zasadniczej). Oznacza to, że zgodnie z art. 91 ust. 1 Konstytucji RP konwencja genewska z 1923 r., jako ratyfikowana umowa międzynarodowa, ogłoszona w Dzienniku Ustaw Rzeczypospolitej Polskiej stanowi część krajowego porządku prawnego.

2. Z rozróżnienia zawartego w dalszej części dyspozycji art. 91 ust. 1 Konstytucji RP wynika, że przepisy ratyfikowanej i ogłoszonej w Dzienniku Ustaw umowy międzynarodowej, będącej częścią krajowego porządku prawnego: albo mogą być bezpośrednio stosowane (w sytuacji, w której dane przepisy zostały ukształtowane w sposób umożliwiający odtworzenie na ich podstawie zupełnych norm prawnych), albo, wówczas gdy nie mają charakteru samowykonalnego, możliwość ich zastosowania w krajowym porządku prawnym jest uzależniona od wydania ustawy, której przepisy dopełnią brakujące elementy normy. Dla niniejszej opinii kluczowe znaczenie ma charakter art. I oraz IV konwencji genewskiej z $1923 \mathrm{r}$. Żaden z nich nie ma charakteru samowykonalnego, ponieważ realizacja ich dyspozycji uzależniona jest w praktyce od zastosowania przepisów prawa krajowego.

Przepis art. I stanowi podstawę dwóch rodzajowo odmiennych obowiązków: procesowego i materialnoprawnego. Po pierwsze, obliguje on do podjęcia przez państwo stronę wszelkich środków w celu wykrycia, ścigania i ukarania sprawcy każdego z „czynów karalnych” wymienionych w dalszej części tego uregulowania (obowiązek procesowy). W tym aspekcie realizacja zaczerpniętego $\mathrm{z}$ konwencji obowiązku nastąpi na podstawie przepisów zawartych w Kodeksie postępowania karnego. Po drugie, z art. I wynika obowiązek materialnoprawny objęcia kryminalizacją w prawie krajowym wszystkich zachowań wymienionych w tym przepisie jako „czyny karalne”. Należą do nich:

1) sporządzanie lub przechowywanie pism, rysunków, rycin, malowidet, druków, wizerunków, afiszów, emblematów, fotografij, filmów kinematograficznych lub innych pornograficznych przedmiotów, w celu handlowania niemi lub rozpowszechniania, bądź publicznego ich wystawiania;

2) wwóz, przewóz, wywóz, bądź zlecenie wwozu, przewozu lub wywozu dla poszczególnych celów pomienionych pism, rysunków, rycin, malowideł, druków, wizerunków, afiszów, emblematów, fotografij, filmów kinematograficznych lub innych pornograficznych przedmiotów, lub puszczanie tychże w obieg w jakikolwiek sposób;

3) handel nawet niepubliczny powyższemi przedmiotami, wszelkie tranzakcje dotyczace ich $w$ jakikolwiek sposób, rozpowszechnianie ich, wystawianie ich publiczne lub zawodowe zajmowanie się ich wypożyczaniem;

4) ogłaszanie lub oznajmianie w jakikolwiek sposób w celu ułatwienia wyżej wzmiankowanego, karalnego obiegu lub handlu, że pewna osoba uprawia którykolwiek z czynów karalnych powyżej wymienionych; ogłaszanie lub oznajmianie w jaki sposób i przez kogo wspomniane pisma, rysunki, ryciny, malowidła, druki, wizerunki, afisze, emblematy, fotografje, filmy kinematograficzne lub inne pornograficzne przedmioty moga być dostarczone bądź wprost, bądź pośrednio. 
Zaprezentowana wyżej charakterystyka czynów nie odpowiada w pełni modelowemu opisowi typu czynu zabronionego, który mógłby stać się samoistną podstawą pociągnięcia sprawcy do odpowiedzialności karnej przed sądami polskimi. Treść konwencji zogniskowano przede wszystkim na prezentacji strony przedmiotowej „czynu karalnego”, wskazując przy tym, jakie zachowania sprawcze powinny być ścigane w porządkach krajowych, identyfikując w sposób konkretny (pisma, rysunki, ryciny, malowidła, druki, wizerunki, afisze, emblematy, fotografie, filmy kinematograficzne) oraz zgeneralizowany (inne przedmioty pornograficzne) przedmioty czynności wykonawczych, na które skierowane jest zachowanie sprawcy, jak również okoliczności popełnienia czynu (publicznie, niepublicznie). Z kolei strona podmiotowa działania sprawcy możliwa jest do zidentyfikowania tylko w odniesieniu do czynów z pkt 1, 2 i 4 - jest nią działanie celowe, natomiast $\mathrm{w}$ przypadku czynów wymienionych pkt 3 kwestia ta została pominięta. Wymogów co do strony podmiotowej nie dotyczy też żaden inny artkuł konwencji. Ponadto konwencja nie identyfikuje rodzajów zagrożenia kary za popełnienie wymienionego w jej treści „czynu karalnego” ani jej wysokości. To przekreśla walor ewentualnej samowykonalności art. I, który nie może stać się samoistną podstawą pociągnięcia sprawcy do odpowiedzialności karnej. Tak więc realizacja konwencyjnego obowiązku zapewnienia kryminalizacji wymienionych w niej zachowań wymaga wprowadzenia do krajowego porządku prawnego odpowiednich typów czynów zabronionych, określonych w ustawie karnej, obejmujących wskazane powyżej, brakujące elementy składowe typu i jego zagrożenia oraz powtarzających elementy wskazane w konwencji lub ich odpowiedniki.

3. Na marginesie, w kontekście zarysowanego we wstępie punktu odniesienia dla wykonywanej analizy, jakim jest kwestia ograniczenia dostępu do pornografii w internecie, warto zwrócić uwagę, że przyjęty w konwencji sposób wysłowienia znamion, które posłużyły do opisania czynów karalnych, był w pełni adekwatny na moment przyjęcia konwencji w roku 1923, w tym sensie, że opisywał rzeczywistość okresu międzywojnia, a nawet jeszcze kilkadziesiąt lat po II wojnie światowej, budzi natomiast wątpliwości, czy przystaje on do opisu rzeczywistości internetowej XXI wieku. O ile jeszcze takie znamiona czynności wykonawczej jak: rozpowszechnianie, publiczne wystawianie, puszczanie w obieg, handel czy ogłaszanie mogłyby znaleźć zastosowanie do opisu zachowań realizowanych przy wykorzystaniu sieci, to obiekty, na które skierowane jest działanie sprawcy (tzw. przedmioty czynności wykonawczych), określone w konwencji jako: pisma, rysunki, ryciny, malowidła, druki, wizerunki, afisze, emblematy, fotografie, filmy kinematograficzne lub inne przedmioty pornograficzne, z uwagi na ich materialny charakter, do cyfrowej rzeczywistości internetu już nie przystają.

Zestawiając kategorię „lub inne przedmioty pornograficzne” z poprzedzającą ją każdorazowo w pkt 1-4 art. I konwencji genewskiej z 1923 r. jej przykładową egzemplifikacją rodzajową, kluczowe będzie spostrzeżenie, że konwencja od- 
wołuje się do pojęcia "przedmiotu” w ujęciu rzeczywistym (materialistycznym), jako dającego się wyodrębnić z rzeczywistości jej materialnego fragmentu, nie zaś abstrakcyjnym, jak np. w sformułowaniu „przedmiot sporu”. Każdy z wykorzystanych w konwencji przykładowych desygnatów „przedmiotu pornograficznego" (pisma, rysunki, ryciny, malowidła, druki, wizerunki, afisze, emblematy, fotografje, filmy kinematograficzne) charakteryzuje się taką materialną właściwością, która, jak się wydaje, powinna stanowić punkt wyjścia dla wykładni tego pojęcia przy okazji poszukiwania innych jego desygnatów, do czego uprawnia zresztą poprzedzająca je figura stylistyczna „lub inne” (przedmioty pornograficzne). Konwencja, posługując się pojęciem „przedmiotów pornograficznych”, w zakresie swojej regulacji odwołuje się w istocie do materialnych nośników „treści pornograficznych", co jest w pełni zrozumiałe, zważywszy na moment dziejowy jej przyjęcia. Specyfiką przekazu internetowego jest natomiast niematerialny zapis cyfrowy.

Z tego względu dla regulacji kwestii pornografii w internecie dużo większą przydatność niż kategoria „przedmioty pornograficzne” ma np. znamię „treści pornograficznych”, wykorzystywane nota bene w obowiązującym Kodeksie karnym. Treści pornograficzne, w oderwaniu od ich nośników, mogą być rozpatrywane w ujęciu abstrakcyjnym (niematerialnym). Zważywszy na to, na gruncie treści konwencji genewskiej z 1923 r. należy przestrzec przed taką próbą wykładni pojęcia „inne pornograficzne przedmioty”, która ukierunkowana zostałaby na objęcie jego zakresem także „przedmiotów niematerialnych”, jak np. w przypadku próby zaaplikowania jej standardów do oceny zachowań podejmowanych przy wykorzystaniu sieci internetowej. Ten sposób interpretacji znamienia „inne przedmioty pornograficzne" mógłby zostać zakwestionowany z perspektywy konstytucyjnej zasady nullum crimen sine lege (art. 42 ust. 1 Konstytucji RP), jako przejaw niedopuszczalnej w prawie karnym wykładni rozszerzającej na niekorzyść sprawcy.

4. Kontynuując kwestię samowykonalności, należy stwierdzić, że w oczywisty sposób nie ma charakteru samowykonalnego także art. IV konwencji genewskiej z 1923 r., zawierający obowiązek państwa strony wystąpienia ze stosowną inicjatywą ustawodawczą prowadzącą do dostosowania prawodawstwa krajowego do standardów konwencji w stopniu wystarczającym dla zapewnienia jej skutków, a więc w istocie obowiązek doprowadzenia do uchwalenia stosownych ustaw. W tym miejscu warto wyeksponować szczególną rangę, jaką w polskich realiach normatywnych zyskał ten obowiązek po tym, jak art. IV konwencji genewskiej z 1923 r. stał się, zgodnie z art. 241 ust. 1 Konstytucji RP, przy zastosowaniu art. 91 ust. $1 \mathrm{w}$ związku z art. 89 ust. 1 Konstytucji RP, częścią polskiego porządku prawnego. Dotyczy to także pozostałych przepisów konwencji, która zgodnie $\mathrm{z}$ art. 91 ust. 2 Konstytucji RP, jako umowa międzynarodowa ratyfikowana za uprzednią zgodą wyrażoną w ustawie, zyskała pierwszeństwo przed ustawą, której nie da się z nią pogodzić (art. 91 ust. 2 Konstytucji RP). W następstwie tego 
Trybunał Konstytucyjny dokonując, stosownie do art. 188 pkt 2 Konstytucji RP, badania hierarchicznej zgodności aktów prawnych, formalnie rzecz biorąc może orzec o niezgodności ustawy z konwencją genewską z $1923 \mathrm{r}$.

5. Zważywszy na zarysowaną wyżej formalnoprawną perspektywę obowiązywania konwencji genewskiej z 1923 r. w polskim porządku prawnym, w którym uzyskuje ona pierwszeństwo przed niezgodną z nią ustawą zwykłą, należy w dalszej kolejności wyeksponować ewidentny dysonans między literą konwencji a zakresem kryminalizacji przyjętym w obowiązującym Kodeksie karnym na gruncie niektórych typów czynów zabronionych z grupy tzw. przestępstw pornograficznych. Kwestia ta nie jest nowa - na sprzeczność np. art. $202 \$ 1$ k.k. z konwencją zwracał uwagę w literaturze przedmiotu m.in. J. Warylewski ${ }^{17}$.

Choć uczestnicy konferencji genewskiej nie zdecydowali się na zdefiniowanie „pornografii”, pozostawiając państwom stronom swobodę w zakresie samodzielnego ustalenia znaczenia tego pojęcia ${ }^{18}$, wyznaczony w jej treści standard kryminalizacji w ustawodawstwach krajowych zachowań z wykorzystaniem „pornograficznych przedmiotów” stanowi wyraz rygoryzmu ruchu antypornograficznego przełomu XIX i XX wieku, zmierzającego do wyrugowania z życia społecznego wszelkiej pornografii, w każdej postaci ${ }^{19}$. Konwencja nie nakazuje wprawdzie kryminalizacji kontaktu z treściami pornograficznymi lub ich nośnikami na warunkach prywatnych (np. u siebie w domu), niemniej czyni wiele, aby dostęp do nich czy możliwość ich pozyskania z rynku wyłączyć. To rygorystyczne podejście zostało zaaplikowane m.in. na gruncie Kodeksu karnego z 1932 r., który w art. $214 \$ 1$ poddawał kryminalizacji rozpowszechnianie pism, druków, wizerunków lub innych przedmiotów, mających charakter pornograficzny, a w art. $214 \$ 2$ wprowadzał typ kierunkowy, polegający na sporządzaniu, przechowywaniu lub przewożeniu pism, druków, wizerunków lub przedmiotów, mających charakter pornograficzny. W obu przypadkach sprawcy czynu groziła kara aresztu do lat 2, a prawodawca nie czynił w opisie typów czynów zabronionych żadnych wyjątków ze względu np. rodzaj pornografii czy zgodę osoby zainteresowanej dostępem do niej. Podobne rozwiązania zostały zaaplikowane także na gruncie Kodeksu karnego z 1969 r. (art. $173 \$ 1$ i 2).

Przyjęty w obowiązującym Kodeksie karnym model kryminalizacji typów zaliczanych do grupy przestępstw pornograficznych oparty jest na odmiennym za-

17 Idem, Rozdział IV. Przestępstwa przeciwko wolności, op. cit., s. 908-909.

18 Z. Cybichowski, Pornografia [w:] Encyklopedia podręczna prawa publicznego (konstytucyjnego, administracyjnego i międzynarodowego, t. II, red. Z. Cybichowski, Warszawa b.r.w., s. 644 .

19 Prace nad nadaniem ram prawnych realizacji tego zamierzenia prowadzone były już wcześniej m.in. na kongresie lozańskim w 1898 r., kongresie paryskim w 1908 r. oraz konferencji paryskiej w 1910 r. Szerzej na temat zob. A. Przyborowska-Klimczak, Zapobieganie i zwalczanie pornografii ws świetle dokumentów międzynarodowych [w:] Pornografia, red. M. Mozgawa, 2011, LEX nr 132679. 
łożeniu aksjologicznym, dopuszczającym pod pewnymi warunkami korzystanie, a z drugiej strony udostępnianie „treści pornograficznych”, o ile chęć zapoznania się z nimi wyrazi osoba dorosła, a same treści nie są związane z udziałem osoby małoletniej, w tym także wykorzystaniem wytworzonego lub przetworzonego wizerunku nieistniejącej osoby małoletniej, prezentowaniem przemocy lub posługiwaniem się zwierzęciem. Możliwość korzystania pod pewnymi warunkami $\mathrm{z}$ treści pornograficznych wywodzona jest tu z wolności słowa obejmującej wolność wyrażania swoich poglądów, ale także pozyskiwania i rozpowszechniania informacji (zob. art. 54 ust. 1 Konstytucji RP oraz art. 10 ust. 1 europejskiej konwencji praw człowieka). Wolność ta nie ogranicza się do informacji, poglądów lub treści odbieranych przychylnie czy postrzeganych jako nieszkodliwe lub obojętne, dotyczy w równym stopniu treści mających charakter bulwersujący, szokujący czy obraźliwy ${ }^{20}$. Nie ma ona jednak charakteru absolutnego, może doznawać ograniczeń ustawowych, co w przypadku „treści pornograficznych”, zwłaszcza zorientowanych na pornografię dziecięcą, przemocową lub zoofilną, znajduje uzasadnienie w ochronie takich wartości jak zdrowie oraz moralność (art. 31 ust. 2 Konstytucji RP oraz art. 10 ust. 2 europejskiej konwencji praw człowieka).

6. Zarysowana wyżej zmiana w podejściu do kwestii ograniczenia dostępu do pornografii, jaka dokonała się w polskim ustawodawstwie od czasu dwudziestolecia międzywojennego, przełożyła się na dekryminalizację pewnych zachowań, co w oczywisty sposób znalazło odzwierciedlenie w obowiązujących przepisach Kodeksu karnego.

Jeśli wziąć za punkt odniesienia pierwszą grupę czynów, których kryminalizacji wymaga konwencja genewska z 1923 r. (tych określonych w art. I pkt 1, jako: sporzadzanie lub przechowywanie pism, rysunków, rycin, malowideł, druków, wizerunków, afiszów, emblematów, fotografij, filmów kinematograficznych lub innych pornograficznych przedmiotów, w celu handlowania niemi lub rozpowszechniania, bądź publicznego ich wystawiania, oraz w części pkt 2: jako wwóz, przewóz, wywóz, bądź zlecenie wwozu, przewozu lub wywozu dla poszczególnych celów...), to ich aktualnego odpowiednika można poszukiwać w typie określonym w art. 202 $\$ 3$ k.k., zgodnie z którym karze pozbawienia wolności do lat dwóch podlega ten, kto w celu rozpowszechniania produkuje, utrwala lub sprowadza, przechowuje lub posiada albo rozpowszechnia lub prezentuje treści pornograficzne z udziałem małoletniego albo treści pornograficzne związane $\mathrm{z}$ prezentowaniem przemocy lub posługiwaniem się zwierzęciem. Abstrahując od pewnych odmienności w ujęciu znamion strony przedmiotowej i podmiotowej (np. konwencja wskazuje dodatkowo na ukierunkowanie działania celem handlu lub publicznego wystawiania), istotne wydaje się wskazanie na odmienne ujęcie przedmiotu

20 Szerzej na temat relacji między granicami kryminalizacji pornografii a wolnością słowa zob. m.in. J. Warylewski, Rozdział IV. Przestępstwa przeciwko wolności, op. cit., s. 909 oraz A. Przyborowska-Klimczak, Zapobieganie i zwalczanie pornografii, op. cit. 
czynności wykonawczej. I nie chodzi tu tylko o to, że konwencja posługuje się znamieniem „przedmiot pornograficzny”, a Kodeks karny „treść pornograficzna”. Zasadnicza różnica wpływająca na zakres kryminalizacji ogniskuje się wokół samego pojęcia pornografii, w szczególności zaś wykorzystania tych jego aspektów, które powinny spotkać się z zakazem ze strony państwa. Standard konwencyjny odnosi się do całej pornografii, podczas gdy na gruncie art. $202 \$ 3$ k.k. ustawodawca uznał za zasadne poddanie kryminalizacji tylko tych treści pornograficznych, które zakładają udział małoletniego, prezentowanie przemocy lub posługiwanie się zwierzęciem. Kwestii produkcji treści pornograficznych (już bez odrębnie stypizowanego celu) dotyczy także typ z art. $202 \S 4 \mathrm{~b}$ k.k., relatywizuje je jednak tylko do treści przedstawiających wytworzony albo przetworzony wizerunek małoletniego uczestniczącego w czynności seksualnej.

W merytorycznej relewancji z drugą grupą czynów określonych w konwencji (chodzi tu o „puszczanie w obieg w jakikolwiek sposób pornograficznych przedmiotów" - art. 1 pkt 2 in fine) pozostają typy określone w art. $202 \$ 1,202$ $\S 4$ b, $202 \$ 3$ oraz 191a $\$ 1$ k.k., przy opisie których ustawodawca skorzystał ze znamion rozpowszechniania lub prezentowania. I w ich wypadku polski ustawodawca modyfikuje zakres kryminalizacji:

- zgodą osoby dorosłej - typ z art. $202 \$ 1$ k.k. (ścigane jest tylko publiczne prezentowanie treści pornograficznych - wszelakich treści - w taki sposób, że może to narzucić ich odbiór osobie, która sobie tego nie życzy), typ $\mathrm{z}$ art. 191a $₫ 1$ (karalne jest rozpowszechnianie wizerunku nagiej osoby lub osoby w trakcie czynności seksualnej bez jej zgody),

- rodzajem treści - typ z art. $202 \S 4$ b k.k. (treści przedstawiające wytworzony albo przetworzony wizerunek małoletniego uczestniczącego w czynności seksualnej),

- potrzebą ochrony potencjalnego adresata (osoby małoletniej poniżej lat 15) przed dostępem do treści pornograficznych - typ z art. $200 \$ 3$ k.k. (karze podlega prezentowanie treści pornograficznych lub udostępnianie przedmiotów pornograficznych albo rozpowszechnianie takich treści w sposób umożliwiający małoletniemu poniżej lat 15 zapoznanie się z nimi).

$\mathrm{Na}$ trzecią grupę czynów składają się zachowania określone jako: handel nawet niepubliczny powyższemi przedmiotami, wszelkie tranzakcje dotyczace ich $w$ jakikolwiek sposób, rozpowszechnianie ich, wystawianie ich publiczne lub zawodowe zajmowanie się ich wypożyczaniem (art. I pkt 3). W odniesieniu do niej aktualne pozostają uwagi poczynione wyżej względem grupy drugiej (art. I pkt 2). Obowiązujący Kodeks karny nie typizuje odrębnie handlu czy wypożyczania treści pornograficznych, tego typu zachowania mieszczą się bowiem w znamieniu rozpowszechniania. Ich odrębna kryminalizacja stanowiłaby zatem superfluum ustawowe. Jak się wydaje, prawodawca podzielał tę ocenę także na gruncie Kodeksu karnego z 1932 r., wówczas również powstrzymał się od 
wprowadzenia tych znamion do ustawowego opisu przestępstw pornograficznych (art. $214 \$ 1$ i 2 ).

Czwarta grupa czynów, których kryminalizacji domaga się konwencja genewska z 1923 r., sprowadza się do zakazu reklamy pornografii. Artykuł I pkt 4 stanowi, że do czynów karalnych należą: ogłaszanie lub oznajmianie w jakikolwiek sposób w celu ułatwienia wyżej wzmiankowanego, karalnego obiegu lub handlu, że pewna osoba uprawia którykolwiek z czynów karalnych powyżej wymienionych; ogłaszanie lub oznajmianie w jaki sposób i przez kogo wspomniane pisma, rysunki, ryciny, malowidła, druki, wizerunki, afisze, emblematy, fotografje, filmy kinematograficzne lub inne pornograficzne przedmioty moga być dostarczone bądź wprost, bądź pośrednio. Na gruncie Kodeksu karnego ustawodawca kryminalizuje prowadzenie reklamy lub promocji działalności polegającej na rozpowszechnianiu treści pornograficznych, ale tylko w określonej sytuacji, a mianowicie, gdy sprawca realizuje to w sposób umożliwiający zapoznanie się z treściami pornograficznymi małoletniemu poniżej lat 15 (art. $200 \$ 5 \mathrm{k} . \mathrm{k}$.). W tym kontekście należy przywołać także typ z art. 202b k.k. w zakresie, w jakim stanowi podstawę do ścigania procederu propagowania zachowań o charakterze pedofilskim.

7. Tytułem uzupełnienia należy wskazać, że polski ustawodawca uznał za zasadne ściganie na gruncie obowiązującego Kodeksu karnego innych społecznie szkodliwych zachowań związanych z rozpowszechnianiem, posiadaniem lub wytwarzaniem treści pornograficznych, a także sui generis przygotowaniem do nich, i określił w związku z tym kolejne typy czynów zabronionych, czyniąc to w sposób wykraczający poza wymagania wyznaczone standardem kryminalizacji konwencji genewskiej z 1923 r. Na podstawie typu określonego w art. 191a $\$ 1$ k.k. ścigane jest na wniosek pokrzywdzonego m.in. utrwalanie wizerunku nagiej osoby lub osoby w trakcie czynności seksualnej z użyciem w tym celu przemocy, groźby bezprawnej lub podstępu, a więc w warunkach przełamania lub wyłączenia swobodnej decyzji woli osoby pokrzywdzonej takim czynem.

W art. $200 \$ 4$ k.k. określony został typ polegający na prezentowaniu małoletniemu poniżej lat 15 wykonania czynności seksualnej, przy założeniu że zachowanie sprawcy ukierunkowane zostało na osiągnięcie zaspokojenia seksualnego siebie lub innej osoby. Za społecznie szkodliwy uznany został nie tylko sam fakt prezentacji (ten aspekt objęty jest już kryminalizacją na podstawie art. 202 $\$ 3$ k.k.), ale głównie towarzysząca mu motywacja sprawcy ukierunkowana na osiągnięcie zaspokojenia seksualnego. Dopełnieniem kryminalizacji zawartej w art. $200 \$ 4$ k.k. jest typ określony w art. $202 \$ 4$ c k.k., na mocy którego karze podlega już samo uczestniczenie $\mathrm{w}$ prezentacji treści pornograficznych $\mathrm{z}$ udziałem małoletniego, pod warunkiem że sprawca działa w celu zaspokojenia seksualnego.

W art. 200a $\$ 1$ i 2 k.k. kryminalizacji poddano zachowania stanowiące sui generis przygotowanie do produkowania lub utrwalania treści pornograficznych z udziałem osób małoletnich poniżej lat 15. Typ określony w art. 200a $₫ 1$ k.k. 
zakłada karalność nawiązywania kontaktu z małoletnim poniżej lat 15 za pośrednictwem systemu teleinformatycznego lub sieci telekomunikacyjnej, zmierzając, za pomocą wprowadzenia go w błąd, wyzyskania błędu lub niezdolności do należytego pojmowania sytuacji albo przy użyciu groźby bezprawnej, do spotkania z nim, przy założeniu, że sprawca działa $w$ celu popełnienia przestępstwa określonego $\mathrm{w}$ art. $197 \$ 3$ pkt 2 (przestępstwo zgwałcenia małoletniego poniżej lat 15 ) lub art. 200 ( $\$ 1$ przestępstwo obcowania płciowego z małoletnim, jak również produkowania lub utrwalania treści pornograficznych, $\$ 3$ i 4 przestępstwa polegające na prezentowaniu treści pornograficznych małoletniemu poniżej lat 15). Z kolei stosownie do art. 200a $\$ 2$ k.k. ściganiu podlega składanie za pośrednictwem systemu teleinformatycznego lub sieci telekomunikacyjnej małoletniemu poniżej lat 15 propozycji obcowania płciowego, poddania się lub wykonania innej czynności seksualnej lub udziału w produkowaniu lub utrwalaniu treści pornograficznych i zmierzanie do jej realizacji.

Na podstawie art. $202 \$ 4$ k.k. ściganiu podlega samo utrwalanie treści pornograficznych z udziałem małoletniego. Dla przypisania odpowiedzialności z tego typu czynu zabronionego nie jest więc istotne ustalenie, po co sprawca utrwala określone treści, innymi słowy, w jakim celu działa. Daleko w sferę prywatności wkracza przepis art. $202 \S 4$ a k.k. Na mocy tego uregulowania zabronione pod groźbą kary stało się już samo przechowywanie, posiadanie lub uzyskiwanie dostępu do treści pornograficznych $\mathrm{z}$ udziałem małoletniego. $\mathrm{Z}$ uwagi na fakt, że powyższe zachowania dotyczą treści pornograficznych $\mathrm{z}$ aspektem pedofilnym, w ocenie ustawodawcy pozostają one społecznie szkodliwe nawet w sytuacji, w której sprawca działałby w warunkach prywatnych, tj. ograniczając się do przechowywania, posiadania lub uzyskiwania dostępu do tych treści tylko na swój prywatny użytek. Dopełnieniem kryminalizacji z art. $202 \$ 4$ b k.k. jest typ czynu zabronionego z art. $202 \S 4 \mathrm{c}$ k.k. w zakresie, w jakim zakazuje przechowywania lub posiadania treści pornograficznych, które przedstawiają wytworzony lub przetworzony wizerunek małoletniego uczestniczącego w czynności seksualnej. Chodzi tu o kryminalizację tzw. pozorowanej pornografii dziecięcej, w związku z pojawieniem się zjawiska zastępowania treści pornograficznych z rzeczywistymi dziećmi treściami pornograficznymi z nierzeczywistymi postaciami dzieci i zaspokajania w ten sposób zapotrzebowania na pornografię dziecięcą bez narażania się na odpowiedzialność karną ${ }^{21}$. Jak wskazują M. Budyn-Kulik i M. Kulik,

${ }^{21}$ V. Konarska-Wrzosek, Komentarz do art. 202 Kodeksu karnego [w:] Kodeks karny. Komentarz, red. V. Konarska-Wrzosek, 2018, LEX nr 571118, nb. 6. Na temat praktyki polegającej na ukazywaniu wizerunków dzieci wygenerowanych komputerowo czy też pornograficznych filmów animowanych, które ukazują sceny z udziałem dzieci, jednakże żadne rzeczywiście istniejące dziecko nie bierze udziału w produkcji takiego filmu (tzw. hentai) zob. M. Mozgawa, Komentarz aktualizowany do art. 202 Kodeksu karnego [w:] Kodeks karny. Komentarz aktualizowany, red. M. Mozgawa, 2018, LEX nr 578892, nb. 20. 
wytworzony wizerunek małoletniego to obraz spreparowany, przedstawiający małoletniego, który w realnym świecie nie istnieje, przetworzony zaś to obraz osoby istniejącej realnie, jednak jej wizerunek został tak zmieniony, że przypomina inną osobę niż ta, którą w rzeczywistości jest ${ }^{22}$.

8. Reasumując, należy stwierdzić, że wykazane wyżej okoliczności związane z obowiązywaniem konwencji genewskiej z 1923 r. w polskim porządku prawnym, w tym jej formalne pierwszeństwo przed niezgodną z nią ustawą zwykłą oraz częściowa niezgodność zakresu typizacji czynów zabronionych zaliczanych na gruncie Kodeksu karnego z 1997 r. do tzw. przestępstw pornograficznych ze standardem kryminalizacji założonym w konwencji, będąca wynikiem decyzji ustawodawcy o dekryminalizacji części zachowań ściganych na gruncie kodeksów karnych z 1932 r. i 1969 r., dowodzą konieczności interwencji legislacyjnej w materię normatywną będącą przedmiotem niniejszej opinii. Nie jest w żaden sposób uzasadnione dalsze utrzymywanie sytuacji, w której w polskim porządku prawnym obowiązują obok siebie przepisy oparte na dwóch niekomplementarnych modelach regulacji pornografii. Pierwszy to model konwencyjny, oparty na przekonaniu o istnieniu uzasadnionej potrzeby wyrugowania z życia społecznego wszelkiej pornografii, w każdej jej postaci, poprzez zablokowanie dostępu jednostek do przedmiotów o charakterze pornograficznym, w tym praktyczne wyłączenie możliwości pozyskania ich z rynku. Drugi to model ograniczonego dostępu, który, na gruncie obowiązującego Kodeksu karnego, dopuszcza możliwość udostępniania, a z drugiej strony korzystania z treści pornograficznych pod pewnymi jednak warunkami. Warunkami tymi są: chęć zapoznania się z nimi wyrazi osoba dorosła, a same treści nie są związane z udziałem osoby małoletniej, w tym także wykorzystaniem wytworzonego lub przetworzonego wizerunku nieistniejącej osoby małoletniej, prezentowaniem przemocy lub posługiwaniem się zwierzęciem.

W zaistniałej sytuacji zachodzi sprzeczność rozwiązań przyjętych na gruncie Kodeksu karnego z postanowieniami Międzynarodowej Konwencji w sprawie zwalczania obiegu i handlu wydawnictwami pornograficznymi, podpisanej w Genewie 12 września 1923 r. W każdej chwili może ona zostać zakwestionowana przez Trybunał Konstytucyjny, który, stosownie do art. 188 pkt 2 Konstytucji RP, jest uprawniony w ramach badania hierarchicznej zgodności aktów prawnych do oceny zgodności przepisów ustawowych ze standardem wyznaczonym przepisami umowy międzynarodowej ratyfikowanej za zgodą w formie ustawy. A taki właśnie status przysługuje w polskim porządku prawnym konwencji genewskiej z 1923 r. na mocy przepisów przejściowych art. 241 ust. 1 Konstytucji RP.

W związku z tym nasuwają się dwie propozycje rozwiązania opisanego problemu. Pierwsza z nich zakłada zaostrzenie przepisów Kodeksu karnego przez po-

22 M. Budyn-Kulik, M. Kulik [w:] Kodeks karny. Czesść szczególna, t. 1, Komentarz. Art. 117-221, red. M. Królikowski, R. Zawłocki, Warszawa 2017, s. 787. 
wrót do rozwiązań obowiązujących na gruncie Kodeksu karnego z 1932 r. oraz Kodeksu karnego z 1969 r. Wydaje się, że to rozwiązanie ma charakter jedynie teoretyczny, gdyż jest mało prawdopodobne, że ustawodawca zdecyduje się na ten krok. Abstrahując od tego, że z uwagi na kazuistyczny sposób ujęcia przestępstw pornograficznych w Kodeksie karnym z 1997 r. samo przywrócenie do porządku prawnego - w miejsce art. $202 \$ 1$ i 2 k.k. - odpowiedników przepisów art. $214 \$ 1$ i 2 k.k. z 1932 r. czy art. $173 \$ 1$ i 2 k.k. z 1969 r. byłoby niewystarczające. Nowe ujęcie należałoby jeszcze zestroić z pozostałymi typami przestępstw pornograficznych. To, jak się wydaje, kluczowe pozostaje, że ocena o potrzebie przywrócenia tak daleko idącej ingerencji państwa w dostęp dorosłych obywateli do wszelkich treści pornograficznych być może łatwiejsza do obrony w początkach wieku XX, wzbudziłaby zasadnicze kontrowersje w wieku XXI.

Zważywszy na to, należy poważnie rozważyć racje przemawiające za innym sposobem na wyeliminowanie stanu sprzeczności między zobowiązaniami w zakresie kryminalizacji czynów zabronionych wynikającymi z konwencji genewskiej z 1923 r. a rozwiązaniami przyjętymi na gruncie Kodeksu karnego. Zakłada on wypowiedzenie konwencji zgodnie z procedurą przewidzianą w jej art. XII w drodze notyfikacji na piśmie pod adresem Sekretarza Generalnego Organizacji Narodów Zjednoczonych. Zakładając częściową dezaktualizację motywów leżących u podstaw przyjęcia konwencji w roku 1923 w jej ówczesnym kształcie, z rozwiązania tego skorzystały już $\mathrm{Dania}^{23}$ i Niemcy ${ }^{24}$. Zasadność wypowiedzenia umowy genewskiej z $1923 \mathrm{r}$. przez stronę polską zaakcentowano również w literaturze prawa karnego ${ }^{25}$.

\section{Podsumowanie}

- W polskim systemie prawa nie występuje całościowa definicja pojęcia pornografii ani jego odpowiedników (np. „treści pornograficznych” czy „materiałów mających charakter pornograficzny), choć wymienione kategorie pojęć zostały wprowadzone do dyspozycji przepisów na gruncie różnych dziedzin prawa, $\mathrm{w}$ tym prawa karnego oraz prawa administracyjnego, a także ratyfikowanych aktów prawa międzynarodowego będących samodzielnym źródłem prawa obowiązującego w Polsce.

23 Oświadczenie rządowe z 6 lipca 1968 r. w sprawie wypowiedzenia przez Danię Konwencji o zwalczaniu obiegu i handlu wydawnictwami pornograficznymi, podpisanej w Genewie 12 września 1923 r., zmienionej protokołem podpisanym w Lake Success 12 listopada 1947 r., Dz.U. 1968, nr 26, poz. 182.

24 Oświadczenie rządowe z 23 października 1974 r. w sprawie wypowiedzenia przez Republikę Federalną Niemiec Konwencji o zwalczaniu obiegu i handlu wydawnictwami pornograficznymi, podpisanej w Genewie 12 września 1923 r., Dz.U. nr 43, poz. 262.

25 J. Warylewski, Rozdział IV. Przestępstwa przeciwko wolności, op. cit., s. 909. 
- Brak całościowego, normatywnego ujęcia terminu pornografia, które przybrałoby formę definicji ustawowej, nie oznacza, że polski ustawodawca całkowicie odrzuca możliwość ujęcia tego pojęcia w ramach rygoru definicji. W obowiązującym systemie prawa można zidentyfikować przypadki, w których ustawodawca dopuścił próby wycinkowego zdefiniowania pornografii w odniesieniu do „pornografii dziecięcej”.

- Zważywszy na dotychczasowy kierunek orzecznictwa Trybunału Konstytucyjnego, dopuszczający stosowanie pojęć ocennych lub językowo nieostrych, pod warunkiem możliwości ustalenia ich desygnatów przy wykorzystaniu kryteriów wypracowanych w doktrynie lub orzecznictwie, nie wydaje się, aby podejście polskiego ustawodawcy, który nie zdecydował się na wytworzenie jednej, zakresowo zupełnej definicji pojęcia „pornografii” ani jego normatywnych odpowiedników (np. „treści pornograficznych” lub „materiałów mających charakter pornograficzny), prowadziło per se do naruszenia konstytucyjnego wymogu poprawnej legislacji (art. 2 Konstytucji RP) czy - na gruncie prawa karnego - określoności czynu zabronionego (art. 42 ust. 1 Konstytucji RP).

- Z uwagi na wskazaną wyżej okoliczność wprowadzenie do polskiego porządku prawnego nowych przepisów ukierunkowanych na ograniczenie dostępu do pornografii $\mathrm{w}$ internecie nie musi bezwzględnie wiązać się z koniecznością ustawowego zdefiniowania tego pojęcia, i to mimo jego ocennego charakteru. Dotyczy to również semantycznych odpowiedników normatywnych pojęcia „pornografia”, takich jak „treści pornograficzne”, „materiały mające charakter pornograficzny" i inne.

- Każda próba całościowego ujęcia w ramach definicji ustawowej pojęcia „pornografii” lub jego semantycznych odpowiedników normatywnych powinna w sposób jurydycznie satysfakcjonujący uwzględnić na gruncie przepisu prawa co najmniej takie kwestie, jak:

- kryteria rozgraniczenia między pornografią i erotyką,

- różnorodność przejawów płciowości i życia seksualnego człowieka,

- $\quad$ kwestia autentyczności i sztucznej kreacji przejawów płciowości i życia seksualnego oraz ich uczestników,

- różnorodność potencjalnych form przekazu lub nośników treści,

- odpowiedź na pytanie o dopuszczalność pornografii w przekazie artystycznym lub naukowym (kontratyp sztuki i nauki).

- Wobec braku oficjalnych informacji o wypowiedzeniu przez stronę polską Międzynarodowej Konwencji w sprawie zwalczania obiegu i handlu wydawnictwami pornograficznymi z 12 września 1923 r. należy uznać, że, zgodnie z art. 241 ust. 1 Konstytucji RP, przy zastosowaniu art. 91 ust. 1 w związku z art. 89 ust. 1 Konstytucji RP, stanowi ona część polskiego porządku prawnego, zaś jej przepisy uzyskały pierwszeństwo przed przepisami każdej ustawy, której nie da się z nią pogodzić (art. 91 ust. 2 Konstytucji RP). 
- Rozwiązania przyjęte w Międzynarodowej Konwencji w sprawie zwalczania obiegu i handlu wydawnictwami pornograficznymi z 12 września 1923 r. oraz w ustawie z 6 czerwca 1997 r. - Kodeks karny oparte zostały na dwóch niekomplementarnych modelach regulacji dostępu do pornografii, co, przy założeniu ich jednoczesnego obowiązywania w polskim systemie prawa, skutkuje zaistnieniem stanu niezgodności zakresu typizacji czynów zabronionych zaliczanych na gruncie Kodeksu karnego z 1997 r. do tzw. przestępstw pornograficznych ze standardem kryminalizacji założonym w konwencji.

- Zakładając częściową dezaktualizację motywów leżących u podstaw przyjęcia Międzynarodowej Konwencji w sprawie zwalczania obiegu i handlu wydawnictwami pornograficznymi, jako sposób na wyeliminowanie stanu sprzeczności przepisów, na który wskazano powyżej, należy rozważyć racje przemawiające za wypowiedzeniem przez Polskę powołanej konwencji, zgodnie procedurą przewidzianą w jej art. XII (notyfikacja wypowiedzenia na piśmie złożona do Sekretarza Generalnego Organizacji Narodów Zjednoczonych).

\section{Bibliografia}

Budyn-Kulik M., Glosa do wyroku SN z dnia 23 listopada 2010 r., IV KK 173/10, LEX nr 125982.

Budyn-Kulik M., Kulik M. [w:] Kodeks karny. Część szczególna, t. 1, Komentarz. Art. 117221, red. M. Królikowski, R. Zawłocki, Warszawa 2017.

Cybichowski Z., Pornografia [w:] Encyklopedia podręczna prawa publicznego (konstytucyjnego, administracyjnego i międzynarodowego), t. II, red. Z. Cybichowski, Warszawa 1926-1930.

Filar M., Pornografia, „Przegląd Ustawodawstwa Gospodarczego” 1993, nr 8-9.

Filar M., Przestępstwa seksualne w nowym kodeksie karnym [w:] Nowa kodyfikacja karna. Kodeks karny. Krótkie komentarze, z. 2, Warszawa 1997.

Konarska-Wrzosek V., Komentarz do art. 202 Kodeksu karnego [w:] Kodeks karny. Komentarz, red. V. Konarska-Wrzosek, 2018, LEX nr 571118.

Mozgawa M., Komentarz aktualizowany do art. 202 Kodeksu karnego [w:] Kodeks karny. Komentarz aktualizowany, red. M. Mozgawa, 2018, LEX nr 578892.

Przyborowska-Klimczak A., Zapobieganie i zwalczanie pornografii w świetle dokumentów międzynarodowych [w:] Pornografia, red. M. Mozgawa, 2011, LEX nr 132679.

Warylewski J., Rozdział IV. Przestępstwa przeciwko wolności seksualnej i obyczajności [w:] System prawa karnego, t. 10, Przestępstwa przeciwko dobrom indywidualnym, red. J. Warylewski, Warszawa 2016. 